\title{
EFFECT OF DIFFERENT NITROGEN SOURCES ON SOME BOTANICAL CHARACTERS OF WHEAT (Triticum aestivum $\mathbf{L}$ ).
}

(Received: 24.3.2010)

\author{
By \\ A. M. Sabbour, E. F. Gomaa and Sh. A. Shaban \\ Department of Agricultural Botany, Faculty of Agriculture, Cairo University
}

\begin{abstract}
This expirment was carried out during the two successive winter seasons 2006 and 2007. Aiming to study the effect of different nitrogen sources; bio fertilizer (Azospirillum brasilense, Bacillus polymyxa, Azotobacter choococcum, Klebsiella pneumonia and pseudomonas putida), organic plant compost, organic cattle manure as well as non organic nitrogen $\left(\mathrm{NH}_{4}\right)_{2} \mathrm{SO}_{4}$ fertilizer on the botanical characters of wheat under sandy soil conditions. The study showed that, non organic nitrogen treatment led to the highest mean values of plant height, number of fertile tillers per plant, average spike length as well as grain yield per plant as compared with all other single used nitrogen sources. Single bio nitrogen treatment caused minute effect on mean performance of the characters under investigation. The yielding ability of wheat plants could be enhanced by the following single nitrogen treatments ranked in ascending order; non organic nitrogen followed by organic cattle manure, organic plant compost and finally bio nitrogen treatments. The treatments of combined nitrogen sources proved to be more convenient in enhancing the studied traits. The highest mean values of the studied traits were recorded on plants that received full non organic + full organic cattle manure treatment followed by those received organic plant compost + non organic nitrogen treatment. Application of various non organic combined with organic nitrogen treatments showed maximum plant height, number of fertile tillers, average spike length and average grain yield per plant.

Stem anatomical measurements of treated plants proved that, all used nitrogen sources caused vital increase in whole stem diameter. These increments were accomplished with changing the investigated nitrogen sources i.e., the non organic nitrogen source achieved the highest increase in stem diameter and the lowest increase was achieved with bio nitrogen treatment. The enlargements in stem wall thickness were reflected on the anatomical features of all tissues shared in stem wall structure; epidermis, sclenchyma belt layer, vascular bundles and the ground parenchyma. The enlargement occurred in stem wall thickness was linked with remarkable increase in the average thickness of ground parenchyma tissue as well as the average vascular bundle diameter. Relative to zero nitrogen treatment all nitrogen sources resulted in a remarkable increase in measurements of all tissues in leaf lamina; thickness of upper and lower epidermis, thickness of mesophyll ground tissue, main vascular bundle length and width, metaxylem vessel diameter and thickness of phloem tissue.
\end{abstract}

Key words: anatomy, bio fertilizer, morphology, organic and non organic fertilizer, wheat (Triticum aestivum $L$ ).

\section{INTRODUCTION}

Wheat (Triticum aestivum L.) belongs to the family Poaceae considered one of the largest families of flowering plants. Wheat is the most important cereal food grown in Egypt. It is grown in about 2.716 million feddan about $17.7 \%$ of the total winter cultivated area (Anonymous, 2009). Nitrogen fertilizer ranks first among the external inputs to maximize output in agriculture. Input efficiency of $\mathrm{N}$ fertilizer is one of the lowest among the plant nutrients and, in turn, contributes substantially to environmental pollution.

Over the last decade the acreage dedicated to organic cropping systems has shown a continuous growth in a number of European countries (Anonymous, 2007). As it is commonly reported in comparisons between organic and conventional cropping systems in industrialized countries (Padel and Lampkin, 1994); the mean values for the organic system were usually lower than for the 
conventional system. The mean yields reflect the fertility level of the systems. The organic yields were considerably higher than in the studies of other continents (Kitchen et al., 2003; Mason et al., 2007 and Murphy et al., 2007). The yield reduction in the organic system varied considerably between countries: from $5 \%$ in barley in Denmark to $47 \%$ for winter wheat in UK. However, the results do not show a clear influence of the difference in productivity between systems on the genetic correlation for yield. Organic matter is regarded as a very important parameter of soil fertility and productivity. Organic matter has the greatest contribution to soil productivity as it provided nutrients to the soil (Zia et al., 1998). In addition organic material may be considered the only safe source of adding nitrogen and can be beneficial to improve organic matter status in sandy soils that are very poor in nutrients. Traditionally manure one of the nutrients which is used to increase soil fertility and crop production by improving their physical nutritional and biological properties. The use of bio-fertilization technique either alone or mixture with bacterial species leads to maximize the counts and activity of such organisms and release plant growth promoting substances which could stimulate plant growth, absorption of nutrient and efficiency of nutrient and metabolism (Brown, 1976; Döbereiner, 1977; Reynders and Valassak, 1982 and Fayez et al., 1985).

The main objective of the present study was to detect the alternatives of the non organic nitrogen fertilizers in wheat production and to study the effect of different nitrogen sources; bio nitrogen, organic compost nitrogen, organic cattle manure nitrogen as well as non organic nitrogen fertilizers on the morphological, anatomical and yield characteristics of wheat under sandy soil conditions. The aim was to find out the most favorable nutrient utilization efficiency, to optimize cost efficiency, to maintain a favorable growth environment for wheat production and keep the environment clean.

\section{MATERIALS AND METHODS}

This expirment was carried out during the two successive winter seasons 2006 and 2007 at the Experimental Farm Station, Department of Agricultural Botany, Faculty of Agriculture, Cairo University. Grains of wheat (Triticum aestivum L) cv. Sakha 93 were sown in well washed sandy soil on $30 \mathrm{~cm}$ pots arranged in the three replicates and five row each. Seeds were soaked about 24 hours before planting in a tap-water in all treatments except biofertilizeration treatments which were soaked in biofertilizer liquid. The experiment contained 14 treatments. All treatments received all the proper agricultural procedures for wheat production according to the estimated recommendations mentioned in the bulletin of the Ministry of Agriculture except the rates of nitrogen fertilizers. As wheat productivity triangle includes the number of fertile tillers per plant, spick lengths as well as average grain yield per plant, the current investigation involved all these three main yield characters measured at the harvest.

For the anatomical study specimens representing the $3^{\text {rd }}$ internode of the stem and its leaf were taken and the anatomical procedures

The investigated nitrogen treatments were as follows

\begin{tabular}{|c|c|}
\hline \multicolumn{2}{|c|}{ Nitrogen Sources (Treatments) } \\
\hline Zero nitrogen (control) & Bio + 0.5 non organic \\
\hline Bio nitrogen* & $\begin{array}{l}\text { Bio }+0.5 \text { organic cattle } \\
\text { manure }\end{array}$ \\
\hline $\begin{array}{l}\text { Non organic }\left(\mathrm{NH}_{4}\right)_{2} \mathrm{SO}_{4},(9 \\
\text { g/ pot })\end{array}$ & $\begin{array}{l}\text { Bio }+0.5 \text { organic plant } \\
\text { compost }\end{array}$ \\
\hline $\begin{array}{l}\text { Organic cattle manure, } \\
\left(350 \mathrm{~cm}^{3} / \text { pot }\right)\end{array}$ & $\begin{array}{l}\text { Bio }+0.5 \text { organic cattle } \\
\text { manure }+0.5 \text { non organic }\end{array}$ \\
\hline $\begin{array}{l}\text { Organic plant compost, } \\
(106 \mathrm{~g} / \text { pot })\end{array}$ & $\begin{array}{l}\text { Bio }+0.5 \text { organic plant } \\
\text { compost }+0.5 \text { non organic }\end{array}$ \\
\hline $\begin{array}{l}\text { Full cattle manure }+ \text { full } \\
\text { non organic }\end{array}$ & $\begin{array}{l}\text { o.5 organoc cattle manure } \\
+0.5 \text { organic compost }\end{array}$ \\
\hline $\begin{array}{l}\text { Full organic plant compost } \\
\text { + full non organic }\end{array}$ & $\begin{array}{l}\text { Bio nitroge }+0.5 \text { organic } \\
\text { cattle manure }+0.5 \\
\text { organic plant compost }\end{array}$ \\
\hline
\end{tabular}

were followed (Nassar and El-Sahhar, 1998). Ten sections of $20 \mu$ representing the main nitrogen treatments were examined. Data were subjected to different methods of statistical analysis according to computer software designed for analysis (MSTAT,1986).

\section{RESULTS AND DISCUSSION}

\subsection{Effect of nitrogen sources on average plant} height

\subsubsection{Main Effect of nitrogen source}

Combined analysis of variance over seasons Table (1) proved that, the source of nitrogen significantly affected the average plant height. Non organic nitrogen source (recommended $\left(\mathrm{NH}_{4}\right)_{2} \mathrm{SO}_{4}$ application) led to the tallest wheat plants as compared with all other single used nitrogen sources. In both seasons, plants that received the recommended non organic nitrogen 
treatment showed 78.7 and $83.4 \mathrm{~cm}$ for the first and second seasons, respectively. The corresponding value obtained over the two seasons was $81.0 \mathrm{~cm}$. Relative to the control, the average increase percentages in plant height due to non organic single application were 65.3 and $61.9 \%$ for the first and second seasons, respectively. This result generally indicates the important role of non organic nitrogen source on promoting the vegetative growth of wheat plants including plant height.

The second investigated nitrogen source was the organic cattle manure. It is clear from Table (1) that this treatment resulted in an increase in plant height but to a lesser extent as compared with the non organic one. Plants treated with organic cattle manure showed prominent increase in average plant height by 40.9 and $38.0 \%$ as compared with the control, in both studied seasons, respectively. However, these plants were stunted by $17.2 \%$ when compared with those treated by the recommended non organic nitrogen. It is obvious that, relative to the control, both used organic and non organic nitrogen sources enhanced the average wheat plant height. Therefore, the decrease in average plant height occurred by organic cattle manure treatment as compared with the non organic may be due to the parameters affecting the inferiority of manure compared with chemical fertilizers, including the low availability and non-uniformity of the nitrogen in manure, and the low level and high non-uniformity of plant-available nitrogen supplied via manure.

Data in Table (1) show the effect of the used organic plant compost on average wheat plant height. It is observable that in both seasons, average plant height was increased due to this treatment as compared with the control. The organic plant compost showed considerable increase over the control by $20.8 \%$ and $20.2 \%$ in both first and second seasons, respectively. However, comparing the non organic and organic plant compost sources proved a dominant effect for the non organic nitrogen source upon the organic plant compost. Where, the average increase percentages in plant height due to non organic nitrogen treatment relative to organic plant compost were, 36.8 and $34.7 \%$ in the first and second season, respectively. The superiority of non organic nitrogen source on organic plant compost nitrogen treatment may be due to the fact that, composting is a biological process in which organic biodegradable wastes are converted into hygienic, hums rich product (compost) for use as a soil conditioner and an organic fertilizer (Popkin, 1995). Like most organisms, Azospirillum uses ammonium salts as a preferred nitrogen source. In the absence of combined nitrogen and under microaerobiosis, the nitrogenase enzyme complex is synthesized and converts atmospheric $\mathrm{N}_{2}$ to $\mathrm{NH}_{4}$ (Dommelen et al., 1998).

The bio nitrogen source effect on the average plant height is illustrated in Table (1). It is clear that plant height of the bio treatment showed significant differences as compared with the control and/or with the other nitrogen sources. Bio nitrogen source produced the shortest wheat plants as compared with all other used nitrogen treatments. Relative to zero nitrogen treatments, in both seasons, plants that received the bio nitrogen treatment exhibited 55.2 and $57.2 \mathrm{~cm}$, for the first and second seasons, respectively. The corresponding value obtained over the two seasons was, $56.2 \mathrm{~cm}$. It is obvious that bio nitrogen treatment presented minute effect on the average plant height. So, regardless of seasons, the mean plant height of single bio treatment was decreased by $30.6,18.6$ and $5.8 \%$ as compared with plants treated with non organic, organic cattle manure and organic compost, respectively. It has been noted that, the benefit of using bio fertilizers as chemical fertilizer substitution is due to the activities of Azospirillum and Azotobacter to fix $\mathrm{N}_{2}$ gas from soil atmosphere (non-symbiotic $\mathrm{N}$ fixer) to become ammonium $\mathrm{N}$. and also due to the increase in particle soil aggregation and soil aeration done by Aspergillus. The beneficial effects of the $\mathrm{N}_{2}$ fixers on plant development can be attributed not only to the $\mathrm{N}$ fixation processes but also to the production of promoting substances; thiamine, nicotinic acid, biotin, pyridoxine ( Harper and Lynch, 1979). Moreover, the simulative effect of bio fertilizer treatment was confirmed by Hani et al. (1998) who stated that the simulative effect of Azorhizobia on plant height could be attributed to plant growth promoting substances excreted by some bacteria.

\subsubsection{Effect of combined nitrogen sources}

For assigning the best combination of the used four nitrogen sources that may affect the mean wheat plant height., data presented in Table (1) proved significant effect of the interaction between the four experimental factors in both seasons and combined over seasons. Generally, regardless the seasons and relative to the control, the following treatments produced relatively the same response towards wheat plant height; bio 
Table (1): Effect of different nitrogen source treatments and their combinations on the mean plant height, number of fertile tillers plant and wheat grain yield in two successive seasons 2007/2008

\begin{tabular}{|c|c|c|c|c|c|c|c|c|c|}
\hline \multirow[t]{2}{*}{ Treatments } & \multicolumn{3}{|c|}{ Average plant height $(\mathbf{c m})$} & \multicolumn{3}{|c|}{ Average number of fertile tillers/plant } & \multicolumn{3}{|c|}{ Average grain yield/plant (g) } \\
\hline & $1^{\text {st }}$ season & $2^{\text {nd }}$ season & Combined & $1^{s t}$ season & $2^{\text {nd }}$ season & Combined & $1^{\text {st }}$ season & $2^{\text {nd }}$ season & Combined \\
\hline Zero nitrogen (control) & $47.6 \pm 0.11$ & $51.5 \pm 0.14$ & $49.5 \pm 0.13 \mathrm{H}$ & $4.20 \pm 0.09$ & $4.47 \pm 0.08$ & $4.33 \pm 0.11 \mathrm{H}$ & $2.16 \pm 0.019$ & $2.29 \pm 0.023$ & $2.23 \pm 0.021 \mathrm{H}$ \\
\hline Bio nitrogen* & $55.2 \pm 0.18$ & $57.2 \pm 0.12$ & $56.2 \pm 0.15 \mathrm{G}$ & $4.40 \pm 0.07$ & $4.70 \pm 0.08$ & $4.55 \pm 0.09 \mathrm{G}$ & $2.18 \pm 0.016$ & $2.27 \pm 0.028$ & $2.23 \pm 0.023 \mathrm{G}$ \\
\hline Non organic $\left(\mathrm{NH}_{4}\right)_{2} \mathrm{SO}_{4}(9 \mathrm{~g} / \mathrm{pot})$ & $78.7 \pm 0.19$ & $83.4 \pm 0.16$ & $81.0 \pm 0.17 \mathrm{~B}$ & $6.07 \pm 0.11$ & $6.50 \pm 0.10$ & $6.28 \pm 0.11 \mathrm{D}$ & $3.17 \pm 0.021$ & $3.21 \pm 0.018$ & $3.19 \pm 0.019 \mathrm{D}$ \\
\hline Organic cattle manure $\left(350 \mathrm{~cm}^{3} / \mathrm{pot}\right)$ & $67.1 \pm 0.21$ & $71.1 \pm 0.19$ & $69.0 \pm 0.20 \mathrm{D}$ & $5.60 \pm 0.08$ & $5.90 \pm 0.11$ & $5.75 \pm 0.09 \mathrm{E}$ & $2.77 \pm 0.027$ & $2.85 \pm 0.027$ & $2.81 \pm 0.027 \mathrm{E}$ \\
\hline Organic plant compost (106g/pot) & $57.5 \pm 0.19$ & $61.9 \pm 0.22$ & $59.7 \pm 0.21 \mathrm{~F}$ & $5.00 \pm 0.07$ & $5.30 \pm 0.10$ & $5.15 \pm 0.09 \mathrm{~F}$ & $2.41 \pm 0.025$ & $2.57 \pm 0.029$ & $2.49 \pm 0.027 \mathrm{~F}$ \\
\hline Full cattle manure + full non organic & $86.9 \pm 0.22$ & $89.2 \pm 0.18$ & $88.0 \pm 0.20 \mathrm{~A}$ & $7.10 \pm 0.12$ & $7.50 \pm 0.13$ & $7.30 \pm 0.12 \mathrm{~A}$ & $3.53 \pm 0.029$ & $3.68 \pm 0.021$ & $3.60 \pm 0.021 \mathrm{~A}$ \\
\hline Organic compost + non organic & $74.6 \pm 0.28$ & $78.8 \pm 0.24$ & $76.7 \pm 0.25 \mathrm{C}$ & $6.80 \pm 0.09$ & $7.20 \pm 0.08$ & $7.00 \pm 0.09 \mathrm{~A}$ & $3.33 \pm 0.028$ & $3.62 \pm 0.026$ & $3.48 \pm 0.027 \mathrm{~A}$ \\
\hline Bio nitrogen + 0.5 non organic & $68.6 \pm 0.31$ & $69.5 \pm 0.26$ & $69.0 \pm 0.26 \mathrm{D}$ & $6.60 \pm 0.08$ & $6.47 \pm 0.06$ & $6.53 \pm 0.08 \mathrm{C}$ & $3.23 \pm 0.022$ & $3.22 \pm 0.021$ & $3.23 \pm 0.021 \mathrm{C}$ \\
\hline Bio nitrogen +0.5 organic cattle manure & $66.1 \pm 0.25$ & $67.5 \pm 0.20$ & $66.8 \pm 0.23 \mathrm{D}$ & $6.20 \pm 0.07$ & $6.60 \pm 0.09$ & $6.40 \pm 0.08 \mathrm{C}$ & $3.04 \pm 0.017$ & $3.38 \pm 0.026$ & $3.21 \pm 0.025 \mathrm{C}$ \\
\hline Bio +0.5 organic plant compost & $62.1 \pm 0.35$ & $65.8 \pm 0.31$ & $63.9 \pm 0.32 \mathrm{E}$ & $6.07 \pm 0.06$ & $6.46 \pm 0.08$ & $6.26 \pm 0.07 \mathrm{D}$ & $2.91 \pm 0.026$ & $3.22 \pm 0.015$ & $3.07 \pm 0.020 \mathrm{D}$ \\
\hline $\begin{array}{l}\text { Bio }+0.5 \text { organic cattle manure }+0.5 \\
\text { non organic }\end{array}$ & $83.1 \pm 0.14$ & $85.0 \pm 0.11$ & $84.0 \pm 0.12 \mathrm{~A}$ & $6.90 \pm 0.07$ & $7.30 \pm 0.08$ & $7.10 \pm 0.09 \mathrm{~A}$ & $3.44 \pm 0.022$ & $3.58 \pm 0.019$ & $3.51 \pm 0.020 \mathrm{~A}$ \\
\hline $\begin{array}{l}\text { Bio + o.5 organic compost + } 0.5 \text { non } \\
\text { organic }\end{array}$ & $71.6 \pm 0.26$ & $75.9 \pm 0.22$ & $73.7 \pm 0.23 \mathrm{C}$ & $7.37 \pm 0.12$ & $7.80 \pm 0.14$ & $7.58 \pm 0.14 \mathrm{~A}$ & $3.73 \pm 0.028$ & $3.82 \pm 0.026$ & $3.78 \pm 0.027 \mathrm{~A}$ \\
\hline $\begin{array}{l}\text { o.5 organic cattle manure }+0.5 \text { organic } \\
\text { compost }\end{array}$ & $67.1 \pm 0.23$ & $71.1 \pm 0.21$ & $69.0 \pm 0.22 \mathrm{D}$ & $6.40 \pm 0.10$ & $6.76 \pm 0.13$ & $6.58 \pm 0.14 \mathrm{~B}$ & $3.24 \pm 0.027$ & $3.31 \pm 0.022$ & $3.28 \pm 0.024 \mathrm{~B}$ \\
\hline $\begin{array}{l}\text { Bio }+0.5 \text { organic cattle manure }+0.5 \\
\text { organic compost }\end{array}$ & $66.9 \pm 0.27$ & $70.9 \pm 0.23$ & $68.9 \pm 0.24 \mathrm{D}$ & $6.82 \pm 0.13$ & $6.90 \pm 0.15$ & $6.86 \pm 0.14 \mathrm{~A}$ & $2.94 \pm 0.023$ & $3.10 \pm 0.028$ & $3.02 \pm 0.024 \mathrm{~A}$ \\
\hline $\begin{array}{l}\text { LSD 5\% Treat.*Season } \\
\text { LSD 5\% Combined }\end{array}$ & 2.8 & 3.1 & 4.2 & 0.99 & 1.01 & 0.82 & 0.89 & 0.81 & 0.79 \\
\hline
\end{tabular}


nitrogen +0.5 non organic, bio nitrogen +0.5 organic cattle manure, 0.5 organic cattle manure + 0.5 organic compost and bio +0.5 organic cattle manure +0.5 organic compost where no significant differences could be detected among the means of such treatments. Moreover, the combined treatment bio nitrogen +0.5 organic plant compost showed relatively an increase in mean plant height as compared with the single bio or organic plant compost treatments. The average increased percentages over these treatments were 13.7 and $7.0 \%$. So, the combined treatments were more efficient in enhancing plant height
However, in both seasons highest values of plant height were recorded on plants that received full non organic + full organic cattle manure treatment 86.9 and $89.2 \mathrm{~cm}$, for the first and second season respectively. The same trend was obtained to a lesser extent on mean plant height in case of organic compost + non organic treatment. Whereby, the recorded plant height averages were 74.6 and $78.8 \mathrm{~cm}$, for the first and second season, respectively. This indicates that organic cattle manure is more favorable to induce more plant height as compared with the organic plant compost. This result reveals the dominant role of

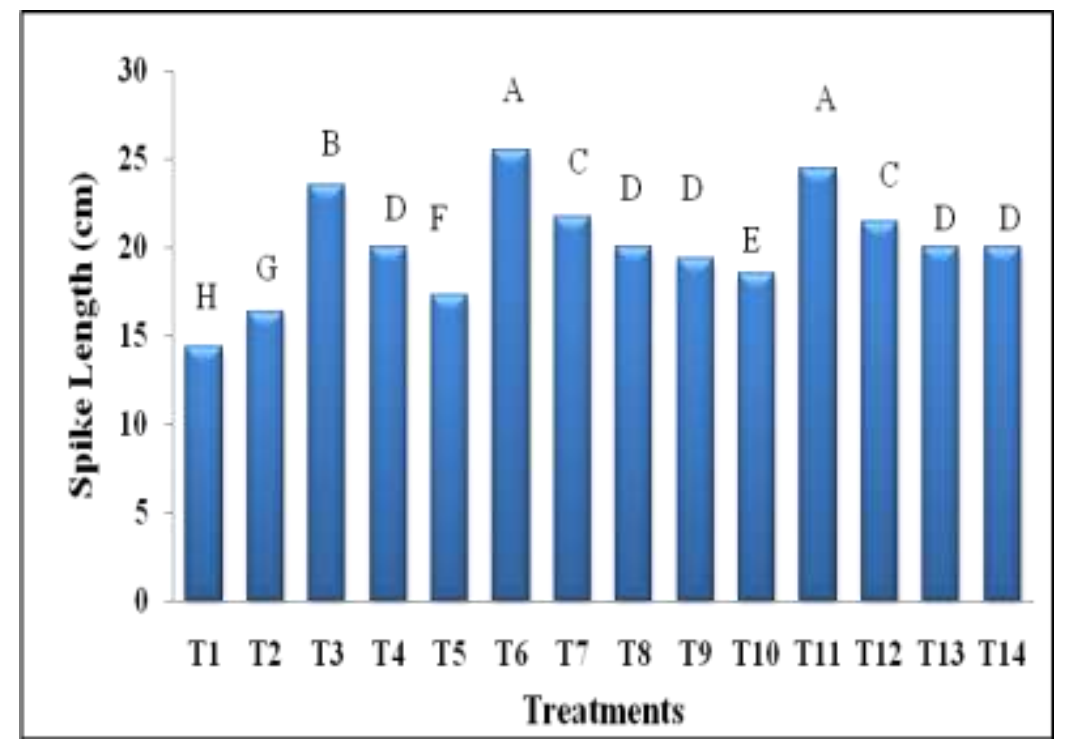

Fig. (1): Effect of different nitrogen treatments and their combinations on the average spike length of wheat plant.

comparable with the single use of bio or organic plant compost. Moreover, the combined bio +0.5 organic cattle manure treatment showed rather increases in wheat plant height. As the average increase percentages for this treatment were, $18.8 \%$ over the single bio treatment, spite of the half used dose of organic cattle manure was applied indicating the important role of $\mathrm{N}$ bio fertilizers in enhancing average plant height when combined with cattle manure. It is worthy to mention that no significant differences where found in the mean height of plants treated with bio +0.5 organic compost and bio +0.5 organic cattle manure +0.5 organic compost.

The interaction effects between non organic nitrogen treatment and organic plant compost and organic cattle manure were significant. As shown in Table (1), the full non organic treatment + full organic cattle treatment gave considerably the tallest plants followed by those treated with bio + 0.5 organic cattle manure +0.5 non organic. non organic nitrogen combined with organic cattle manure on the average height of wheat plant.

\subsection{Effect of nitrogen sources on average spike length}

\subsubsection{Main Effect of nitrogen source}

Data presented in Fig. (1) illustrate the main effects of different nitrogen sources on the average spike length. It is evident that non organic nitrogen treatment produced the tallest spikes as compared with all other investigated nitrogen treatments. In both seasons, the recommended non organic nitrogen treatment showed 22.8 and 24.2 $\mathrm{cm}$, for the first and second seasons. The equivalent recorded spike length over the two seasons was, $23.5 \mathrm{~cm}$. Non on organic treatment proved to be the best for enhancing the average wheat spike length among the other nitrogen treatments. This finding is reflecting the important role of non organic nitrogen source on promoting the vegetative growth of wheat plants including average spike length. 
The organic cattle manure treatment resulted in an increase in spike length per plant but not to a lesser degree as compared with the non organic one. Organic cattle manure showed prominent increase in the average spike length by $43.1 \%$ as compared with the zero nitrogen treatment, combined over the two seasons. Nevertheless, organic cattle manure spike length was reduced by $14.7 \%$ when compared with the recommended non organic nitrogen.

As shown in Fig. (1) organic plant compost in both seasons, increased the average spike length by 27.3 and $20.5 \%$ as compared with the control in both the first and the second seasons, respectively. Comparing the non organic and organic plant compost treatments proved the dominant effect for the non organic nitrogen treatment upon the organic plant compost. The superiority of non organic nitrogen source on organic plant compost nitrogen treatment in different plant species was confirmed by many workers among them; Popkin (1995) and Dommelen et al. (1998). Moreover, Sarwar et al. (2008) found that, spike length of rice and wheat increased significantly by the addition of organic materials alone and with chemical fertilizers.

Bio nitrogen treatment significantly affected the average spike length per plant. In view of the fact that bio nitrogen treatment performed the shortest wheat spikes as compared with all other used nitrogen treatments. Relative to zero nitrogen treatment, in both seasons, plants that received bio nitrogen treatment exhibited spikes length 8.0 and $8.6 \mathrm{~cm}$, for the first and second seasons, respectively. In addition, combined seasons data proved that, spike length of bio treatment was decreased by $44.2,22.9$ and $6.2 \%$ as compared with plants treated with; non organic, organic cattle manure and organic compost, respectively. Sabry et al. (2000) reported that wheat inoculated with azorhizobia under zero nitrogen level significantly increased plant spike length. On the contrary, the obtained results showed no stimulant effect due to bio treatment alone was recognized while, the combined bio nitrogen treatments showed enhancement effect.

\subsubsection{Effect of combined nitrogen sources}

The combination of the investigated nitrogen sources showed significant effect between the experimental four nitrogen types in both seasons and combined over seasons. It is obvious that, the following the combined treatments exhibited comparable same effect on the average spike length; Bio nitrogen +0.5 non organic, Bio nitrogen +0.5 organic cattle manure, 0.5 organic cattle manure +0.5 organic compost and Bio +0.5 organic cattle manure +0.5 organic compost, Figure (1). No significant differences could be detected among the means of such treatments. Moreover, the effect of the combined treatment bio nitrogen +0.5 organic plant compost) showed relatively an increase in mean spike length as compared with the single bio or organic plant compost treatments.

It could be stated that all combined treatments were more efficient in enhancing mean spike length comparable with single use of bio, organic and non organic treatments. Moreover, the combined treatment Bio +0.5 organic cattle manure showed the same effect of 0.5 organic cattle manure +0.5 organic plant compost. The results indicated that bio treatment combined with 0.5 organic cattle manure may offer equivalent effect of that obtained from organic plant compost. It is worthy to mention that no significant differences were found in mean spike length per plant with $\mathrm{Bio}+0.5 \mathrm{~N}$ organic compost and bio +0.5 organic cattle manure +0.5 organic compost. Moreover, the full non organic treatment + full organic cattle treatment gave considerably the tallest spikes followed by those treated with Bio +0.5 organic cattle manure +0.5 non organic. This assigned the importance of organic cattle manure for enhance spike length as compared with organic plant compost. The superior effects of non organic nitrogen treatments and the organic cattle manure alone or combined together was confirmed by many investigators. Whereby, the organic substances play a direct role in sustaining soil fertility, as they are sources of plant nutrients, which liberate inavailable form during mineralization (Smith and Harpley, 1990). Also it is recognized that organic materials differ in their efficiency as fertilizers according to their origin (Ibrahim et al.,1988). The combined application of organic and inorganic $\mathrm{N}$ fertilizers resulted in reducing $\mathrm{N}$ losses from chemical $\mathrm{N}$ fertilizer and increasing the amount of $\mathrm{N}$ mineralization from organic $\mathrm{N}$ source (Azam et al.,1985). That is called "Positive priming effect" or adding nitrogen interaction of the applied material on apparent Soil-N mineralization as mentioned by Jenkinson et al. (1985). Mean fluctuation within different nitrogen source treatments found in this study strongly emphasized the importance of apparent net nitrogen release. Since, ANNR from nitrogen sources depended mainly on the soil conditions, 
chemical composition and the climate (Metwally and Khamis, 1998).

\subsection{Effect of nitrogen sources on average number of fertile twigs per plant}

\subsubsection{Main Effect of nitrogen source}

Statistically, all studied nitrogen treatments significantly affected the mean of such trait, (Table 1). Generally, the average number of twigs per plant differed according to the source of nitrogen. Single nitrogen source treatments always produced lesser averages of twigs per plant compared with the combined treatments. In both seasons, bio nitrogen showed no significant differences as compared with their relative control. Regardless of the season, the average recorded number of fertile twigs per plant of bio nitrogen was 4.55 twigs compared with 4.33 twigs for the control. So, it could be stated that, single bio fertilizer treatment did not promote the average number of fertile twigs per plant.

The organic plant compost showed outstanding increases in average twigs per plant as compared with zero nitrogen treatment. It is noticed that, relative to zero treatment, in both seasons, the average numbers of twigs per plant were increased by 19.0 and $18.6 \%$ in the first and second seasons, respectively. However, comparing the non organic and organic plant compost treatments showed the foremost effect of the non organic nitrogen treatment over the organic plant compost treatment. Where, the average increased percentages in the number of twigs due to non organic treatment relative to organic compost were, 21.4 and $22.6 \%$ in the first and second season, respectively.

Comparing the main effect of the organic plant compost with the organic cattle manure showed increased percentages by 21.0 and $11.3 \%$ for the first and second seasons, respectively. The corresponded percentages between the organic plant compost and bio treatments were, 13.6 and $12.7 \%$. It could be stated that plant compost is likely ranked as the third effective source of nitrogen to enhance number of fertile twigs in wheat plant as compared with the non organic and organic cattle treatments.

The investigated cattle manure treatment significantly affected the average number of twigs per plant in both seasons. Relative to zero treatment cattle manure resulted in 33.3 and $32.0 \%$ increase in the number of fertile twigs per plant. Comparing the organic cattle manure with the non organic treatment proved lower efficiency for enhancing the average number of twigs per plant.

The effect of non organic nitrogen on the average number of twigs per plant in both seasons showed remarkable enhancement compared with zero nitrogen. However, numbers of twigs per plant were reduced when comparison was held between the recommended non organic nitrogen and the bio nitrogen treatment. Moreover, it is obvious that non organic showed the highest recorded number of twigs per plant. Regardless of the seasons, the average increased percentages due to non organic nitrogen in the means of such trait as compared with the other nitrogen treatments; bio, organic plant compost and organic cattle manure were, $38.02,21.9$ and $9.2 \%$ for the three studied treatments arranged in the same order.

\subsubsection{Effect of combined nitrogen sources}

Combined nitrogen effect proved that, in both seasons no significant differences were detected in the average number of twigs per plant between combined treatment Bio +0.5 organic plant compost +0.5 non organic and Bio +0.5 organic cattle manure +0.5 non organic. This indicates that these two combined treatments showed the same effects. No significant differences were found between the non organic recommended treatment and these two combined treatments indicating that using any of these combined treatments Bio +0.5 organic plant compost and/or Bio +0.5 organic cattle manure +0.5 organic plant compost could be used as an alternative to the recommended non organic recommended treatment for enhancing number of fertile twigs per plant. So, it could be stated that, in the presence bio nitrogen source, using half recommended non organic nitrogen concentration or half the recommended organic cattle manure treatments gave the same effects on the average number of twigs per plant. Moreover, the highest recorded numbers of fertile twigs per plant were recorded with the bio +0.5 organic plant compost +0.5 non organic treatment followed by non organic + organic cattle treatments. Relative to the recommended non organic treatment and over the two studied seasons, the average increased percentages due to these treatments were, 20.7 and $16.2 \%$ for bio +0.5 compost +0.5 non organic treatment followed by non organic + organic cattle treatment, respectively. This was confirmed by Attallah et al. (1997) and Zahir et al. (2007).

\subsection{Effect of nitrogen sources on average grain yield per plant}

3.4.1. Main Effects of nitrogen source 
Data related to the average wheat grain yield per plant as affected by different nitrogen treatments are presented in Table (1). Grain yield per plant was significantly affected as the source on nitrogen treatment changed. Single nitrogen source treatments discouraged the averages grain yield per plant compared with the combined nitrogen source treatments. In both seasons, bio nitrogen showed no significant differences as compared with their relative control. It could be stated that, bio treatment alone did not promote the average grain yield per plant. On the contrary, the organic plant compost showed increases in grain yield per plant as compared with zero nitrogen treatment. Nevertheless, non organic treatment and organic plant compost treatments showed the foremost effect. As, the non organic nitrogen treatment gained the highest yield as compared with the organic plant compost treatment. Whereby, the average increased percentages of grain yield per plant due to the non organic treatment relative to organic plant compost were, 31.5 and $24.9 \%$ in the first and second season, respectively. Comparing the effect of the organic plant compost with the organic cattle manure showed increased percentages by 14.9 and $10.8 \%$ for the first and second seasons, respectively. While, the relative increased percentages between the organic plant compost and bio treatments were, 10.5 and 13.2. The effect of organic plant compost on the grain yield of wheat was previously studied by El-Sharaway et al. (2003). Their findings are in agreement with the above mentioned results with concern the main effects of organic plant compos on the wheat yield components attributes. Concerning the main effect of the organic cattle manure it is clear that this treatment significantly increased the average grain yield per plant as compared with the other nitrogen treatments except that of non organic nitrogen treatments. Whereby, relative to zero treatment organic cattle manure treatment increased grain yield by 28.2 and $24.4 \%$ in both first and second seasons, respectively. It is also noticed that organic cattle manure proved to high efficiency for enhancing the average grain yield per plant as compared with both organic plant compost and bio nitrogen treatments. Furthermore, the average decreased percentages due to the organic cattle manure relative to the non organic recommended treatment were, 12.6 and $11.2 \%$ for the first and second season, respectively. These findings indicated that average grain yield of wheat plants could be enhanced by following single nitrogen treatments ranked in ascending order; non organic, organic cattle manure, organic plant compost and finally bio nitrogen treatments. These findings emphasized that, application of various non organic and organic amendments on different yield parameters gave maximum plant height, number of fertile tillers and total plant biomass. Swarup and Yaduvanshi, (2000). 'Kuepper, (2003) and Sarwar et al. (2008), reported that yield of wheat increased significantly with the use of chemical fertilizer alone or in combination with various organic farm manure and plant compost.

\subsubsection{Effect of combined nitrogen sources}

In both seasons no significant differences were detected in the average grain yield per plant between combined treatments, full cattle manure + full non organic and organic compost + non organic. This indicates that these two combined treatments showed the same effects. Relative to zero nitrogen treatment, these treatments enhanced the average grain yield per plant by 56.0 and $61.4 \%$. Whereas, no significant differences were found between the Bio nitrogen +0.5 non organic and Bio +0.5 cattle manure indicating that using any of these combined treatments gave the same effect on average grain yield per plant. So, adding bio nitrogen source, with the half recommended non organic nitrogen or half organic cattle manure treatments showed the same yielding ability. The highest recorded grain yield per plant was recorded with Bio +0.5 organic cattle manure + 0.5 non organic treatment followed by the full non organic + full organic cattle manure treatment. It could be stated that these two treatments could be used as alternative recommendation for induction of high grain yield per plant.

\subsection{Effect of nitrogen sources on stem anatomical structure}

Data contributing to the effect of different nitrogen sources on the anatomical measurements and counts of the stem as shown in transverse sections are presented in Table (2) and Fig. (2). It is realized that, relative to the zero nitrogen treatment, all used nitrogen sources caused vital increase in whole stem diameter. These increments were accomplished with changing the investigated nitrogen sources i.e., the non organic nitrogen source achieved the highest increase in stem diameter $68.2 \%$. While, the lowest increase in average stem diameter was achieved with bio nitrogen treatment $15.1 \%$. The increases in stem diameter were reflected on the anatomical features of all tissues shared in stem wall structure; 
Table (2): Means of measurements ( $\mu$ ) and counts of different tissues as shown in the transverse sections of the $3^{\text {rd }}$ internode of wheat stem $3^{\text {rd }}$ internode treated by different nitrogen fertilizers (average of 10 readings).

\begin{tabular}{|c|c|c|c|c|c|c|c|c|c|}
\hline Characters & Zero & Bio & $\begin{array}{c} \pm \% \text { to } \\
\text { zero }\end{array}$ & $\begin{array}{c}\text { Plant } \\
\text { compost }\end{array}$ & $\begin{array}{l} \pm \% \text { to } \\
\text { zero }\end{array}$ & $\begin{array}{c}\text { Cattle } \\
\text { manure }\end{array}$ & $\begin{array}{c} \pm \% \text { to } \\
\text { zero }\end{array}$ & $\begin{array}{c}\text { Non } \\
\text { organic }\end{array}$ & $\begin{array}{l} \pm \% \text { to } \\
\text { zero }\end{array}$ \\
\hline Stem diameter $(\mu)$ & 3529.8 & 4062.6 & 15.1 & 4728.6 & 34.0 & 5727.6 & 62.3 & 5938.2 & 68.2 \\
\hline Stem wall thickness $(\mu)$ & 366.3 & 499.5 & 36.4 & 566.1 & 54.5 & 566.1 & 54.5 & 599.4 & 63.6 \\
\hline Hollow pith diameter $(\mu)$ & 2797.2 & 3063.6 & 9.5 & 3596.4 & 28.6 & 4195.7 & 50.0 & 4283.4 & 53.1 \\
\hline Epidermis thickness $(\mu)$ & 9.3 & 12.5 & 35.1 & 13.7 & 48.1 & 13.7 & 48.1 & 15.9 & 71.9 \\
\hline Hypodermis sclernchyma belt $(\mu)$ & 63.0 & 72.4 & 14.9 & 75.8 & 20.3 & 77.2 & 22.5 & 80.2 & 27.3 \\
\hline No. vascular bundles & 47.0 & 46.0 & -2.1 & 46.5 & -1.1 & 44.1 & -6.2 & 43.5 & -7.4 \\
\hline $\begin{array}{l}\text { Vascular bundle } \text { Length }(\mu) \\
\text { Width }(\mu)\end{array}$ & $\begin{array}{l}162.5 \\
125.0\end{array}$ & $\begin{array}{l}187.5 \\
162.5\end{array}$ & $\begin{array}{l}15.4 \\
30.0\end{array}$ & $\begin{array}{l}219.3 \\
170.0\end{array}$ & $\begin{array}{l}35.0 \\
36.0\end{array}$ & $\begin{array}{l}225.0 \\
198.4\end{array}$ & $\begin{array}{l}38.5 \\
58.7\end{array}$ & $\begin{array}{l}259.0 \\
204.8\end{array}$ & $\begin{array}{l}59.4 \\
63.8\end{array}$ \\
\hline Average vessel diameter $(\boldsymbol{\mu})$ & 37.0 & 57.4 & 55.1 & 61.8 & 67.0 & 62.5 & 68.9 & 70.9 & 91.6 \\
\hline Bundle sheath thickness $(\mu)$ & $\mathbf{1 2 . 5}$ & 12.6 & 0.80 & 12.5 & 0.00 & 12.4 & 0.80 & 12.3 & -1.60 \\
\hline
\end{tabular}

Table (3): Means of measurements ( $\mu$ ) of different tissues as shown in the transverse sections of wheat leaf treated with different nitrogen source fertilizers (average of 10 readings).

\begin{tabular}{|c|c|c|c|c|c|c|c|c|c|}
\hline Characters & Zero & Bio & $\begin{array}{c} \pm \% \text { to } \\
\text { zero }\end{array}$ & $\begin{array}{c}\text { Plant } \\
\text { compost }\end{array}$ & $\begin{array}{c} \pm \% \text { to } \\
\text { zero }\end{array}$ & $\begin{array}{c}\text { Cattle } \\
\text { manure }\end{array}$ & $\begin{array}{c} \pm \% \text { to } \\
\text { zero }\end{array}$ & $\begin{array}{c}\text { Non } \\
\text { organic }\end{array}$ & $\begin{array}{c} \pm \% \text { to } \\
\text { zero }\end{array}$ \\
\hline Average thickness of leaf lamina & 734.4 & 882.1 & 20.1 & 896.4 & 22.0 & 917.5 & 24.9 & 985.4 & 25.4 \\
\hline Thickness of upper epidermis & 26.7 & 28.4 & 6.3 & 28.9 & 8.2 & 31.4 & $\mathbf{1 7 . 6}$ & 34.9 & 23.4 \\
\hline Thickness of lower epidermis & 17.1 & 18.2 & 6.4 & 18.6 & 8.7 & 18.9 & 10.5 & 19.1 & 10.4 \\
\hline Thickness of ground spongy parenchyma & 694.4 & 835.2 & 20.2 & 844.1 & 21.5 & 888.6 & 27.9 & 932.7 & 25.5 \\
\hline Average parenchyma cell diameter & 86.8 & 96.1 & 9.7 & 106.7 & 22.9 & 112.4 & 29.5 & 116.3 & 34.0 \\
\hline Main vascular bundle length & 233.8 & 267.2 & 14.2 & 310.2 & 32.6 & 384.1 & 64.2 & 402.3 & 72.0 \\
\hline Main vascular bundle width & 221.8 & 257.6 & 16.1 & 301.4 & 35.8 & 376.1 & 69.5 & 396.4 & 78.7 \\
\hline Average phloem thickness & 83.9 & 88.1 & 5.0 & 102.6 & 22.2 & 111.3 & 27.4 & 124.9 & 48.8 \\
\hline Average diameter of metaxylem vessel & 35.05 & 35.2 & 0.4 & 35.8 & 2.1 & 41.7 & 19.0 & 43.8 & 25.0 \\
\hline Average thickness of bundle sheath & 63.5 & 66.4 & 4.4 & 69.1 & 8.8 & 78.9 & 24.3 & 89.1 & 40.3 \\
\hline
\end{tabular}




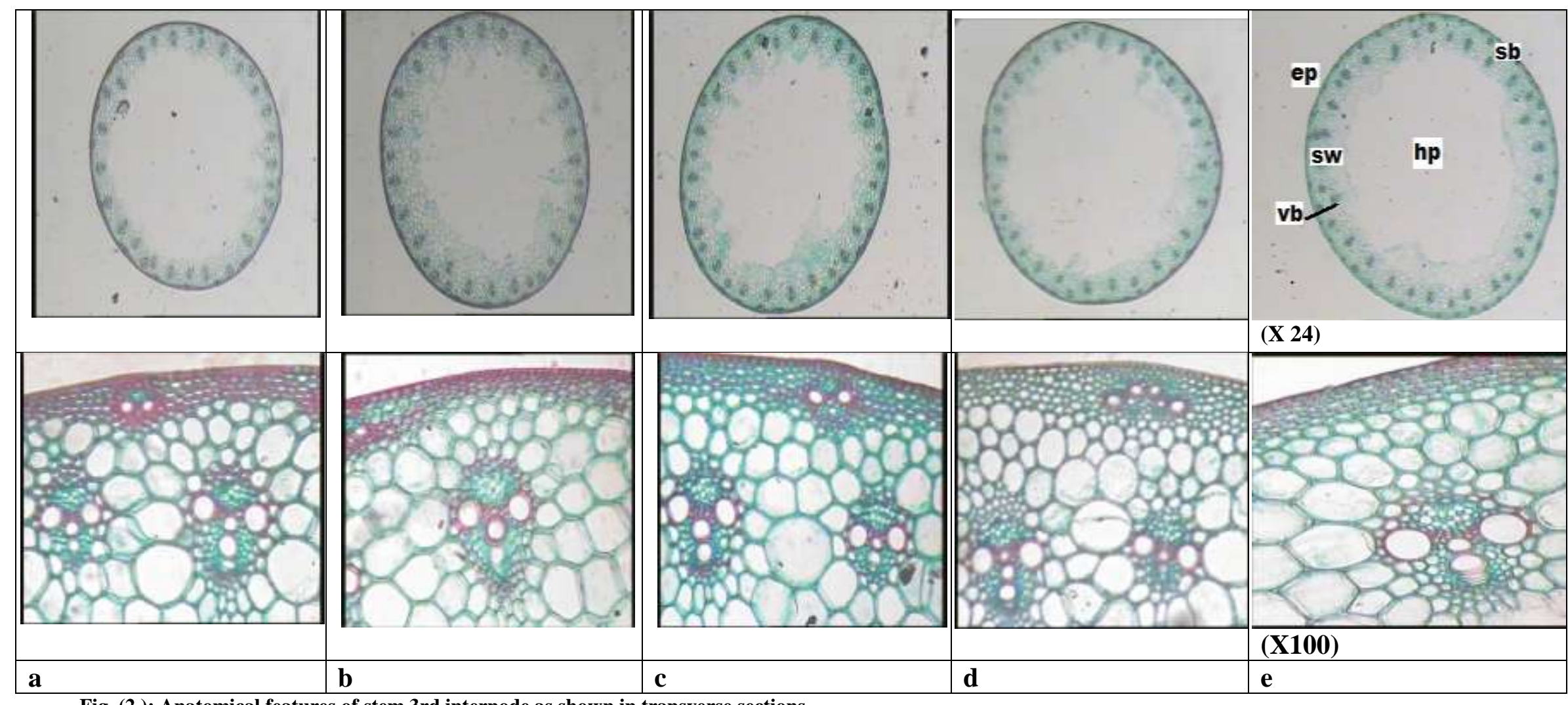

Fig. (2 ): Anatomical features of stem 3rd internode as shown in transverse sections.

Zero nitrogen treatment, b) bio nitrogen treatment, c) organic compost nitrogen treatment, d) Organic cattle manure nitrogen treatment, e) non organic nitrogen treatment. Details: ep: epidermis; sw: stem wall; sb: sclernchyma belt; vb: vascular bundle and hp: hollow pith. 
epidermis, sclenchyma belt layer, vascular bundles and the ground parenchyma. The enlargement occurred in stem wall thickness due to different nitrogen source treatments was linked with remarkable increase in the average thickness of ground parenchyma tissue as well as the average vascular bundle diameter. It is also evident that different sources of nitrogen greatly altered the stem wall thicknesses. Relative to zero nitrogen the average increases in stem wall thickness were, $36.4,54.5,54.5$ and $63.6 \%$ for the different nitrogen sources arranged as follows; bio, compost, cattle manure and non organic nitrogen sources, respectively. These increments in stem wall thickness were correlated with another increase in the thickness of the hypodermal stem sclernchymatous belt. Stem parenchymatus ground tissue showed the major response to different nitrogen source treatments. The highest average diameter of the ground tissue parenchyma cells was recorded with the non organic treatment followed by the organic cattle manure nitrogen treatment. While, both zero nitrogen and bio nitrogen treatments produced relatively thin parenchyma cells as compared with the other investigated nitrogen sources. On the contrary, remarkable decrease $7.4 \%$ was noticed in the number of vascular bundles due to non organic nitrogen treatment (Fig. 2). It is also noticed that, both bio and organic plant compost treatments showed relatively equal number of vascular bundles. The amount of reduction occurred in number of vascular bundles was associated with an increase in vascular bundle diameter length $\mathrm{X}$ width. The non organic nitrogen treatment scored the largest vascular bundles as compared with the other investigated sources; bio, organic compost and organic cattle manure.

Relative to zero nitrogen treatment, the average increases in length of the vascular bundle were, 15.4, 35.0, 38.5 and $59.4 \%$ for the different nitrogen sources arranged as follows; bio, organic plant compost, organic cattle manure and non organic treatments, respectively. Same trend of increments were recorded being realized in average vascular bundle width. Furthermore, the increment occurred in vascular bundle length and width was linked with remarkable increase in average metaxylem vessel diameter. Where, the widest vessel diameter $70.9 \mu$ was recorded with non organic treatment while bio nitrogen fertilizer maintained the narrowest one $55.1 \mu$. Moreover, both organic compost and organic cattle manure exhibited relatively the same metaxylem vessel diameter. No remarkable differences were found between the thicknesses of vascular bundle fibrous sheath of different nitrogen treatments.

The above mentioned results are in accordance with the findings of Mohamed (2000). He concluded that, mineral fertilizers, especially at the rate of $100 \%$ positively increased stem structure by $31.15 \%$ for section diameter, $53.41 \%$ in thickness of fiber layer, $41 \%$ in ground tissue thickness, $20 \%$ in the number of ground tissue layers, $17.54 \%$ in average of ground tissue cell, $36.36 \%$ in number of vascular bundles, 86.67 and $19.15 \%$ in length and width of vascular bundle and $60 \%$ in the average diameter of metaxylem vessels compared with those of untreated plants. On the contrary, Forrest and Young (2006) stated that, internode anatomy was unaffected by either nitrogen fertilizer type or nitrogen level as nitrogen level did not have significant effects on tissue ratios. In addition, Huang et al. (1994) mentioned that, neither the diameter nor the number of xylem vessels were affected by increasing $\mathrm{N}$ supply. These findings are not matching with the present results wherein the internode anatomical characteristics were significantly affected by nitrogen fertilizer type. Moreover, xylem area and volume as well as the average diameter of ground tissue were appreciably bigger with the non organic nitrogen treatment as compared to the control and/or organic and bio nitrogen treatments. As well, stem wall thickness was remarkably thicker with non organic nitrogen treatment than the control. Two anatomical characteristics were not influenced by nitrogen fertilizer type the number of vascular bundles and the average thickness of the vascular bundle fibre sheath. This is in contrast to previous findings of Mohamed, 2000 who stated that treatments with $100 \%$ recommended non organic nitrogen fertilizer increased the number of vascular bundles in stem cross section. It is worthy to mention that in monocot stems vascular bundles mainly initiated in early growth stage within the apical meristem that may not be affected by nitrogen type or level.

\subsection{Effect of nitrogen sources on leaf anatomical structure}

Microscopic measurements and counts as detected in leaf blade transverse sections of wheat plant treated by different nitrogen source types; zero nitrogen, bio nitrogen, organic compost nitrogen, cattle manure nitrogen as well as non organic nitrogen are presented in Table (3) and Fig. (3). It is obvious that, all measurements of 


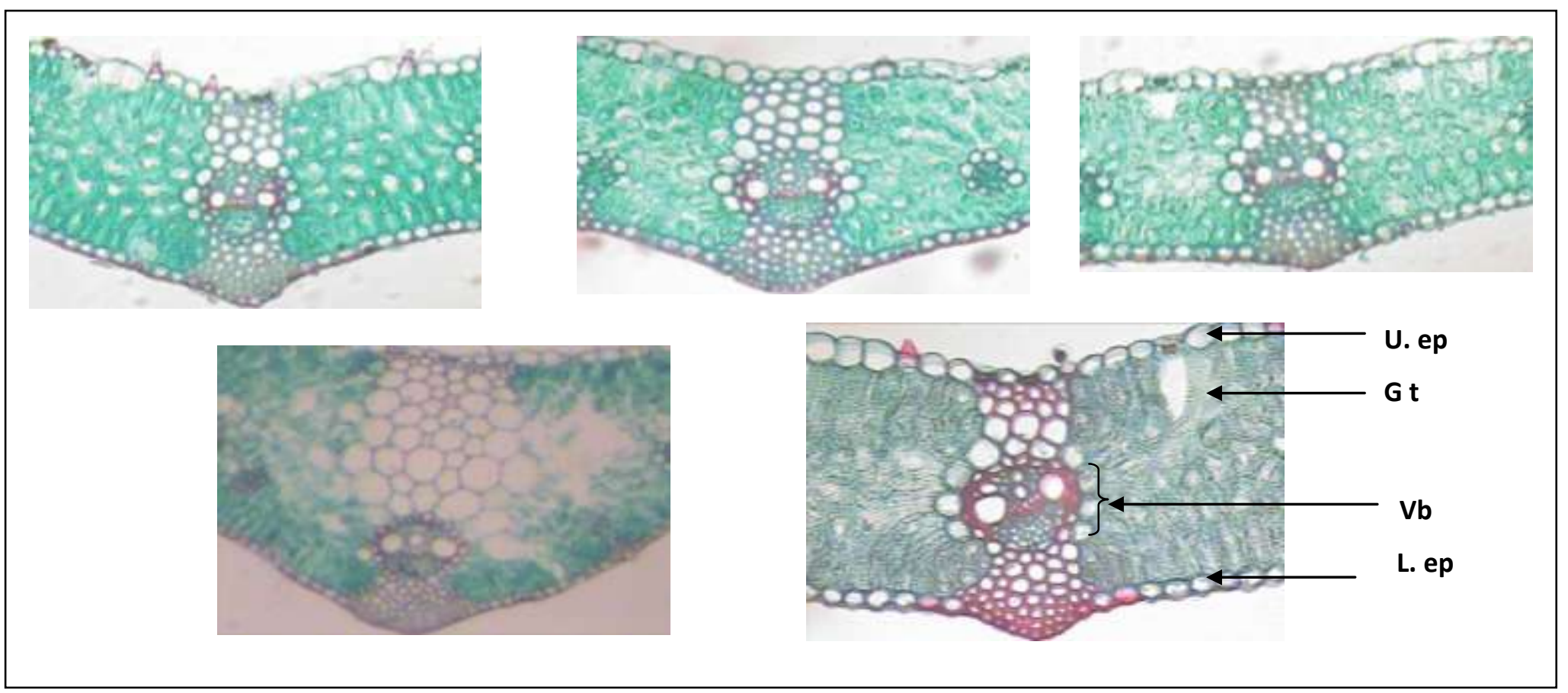

Fig. (3 ): Anatomical features of wheat leaf as shown in transverse sections.

a) Zero nitrogen treatment, b) bio nitrogen treatment, c) organic compost nitrogen treatment, d) organic cattle manure nitrogen treatment and e) non organic nitrogen treatment. Details: U.ep) upper epidermis, Gt) Ground tissue, Vb) vascular bundle and L.ep) Lower epidermis. 
certain anatomical characters of all nitrogen treated plants showed a remarkable increase as compared with their respective controls. Since, the measurements of the following anatomical features were appreciably increased with remarkably different extents; thickness of leaf lamina, thickness of upper and lower epidermis, thickness of mesophyll ground tissue, main vascular bundle length and width, metaxylem vessel diameter as well thickness of phloem and thickness of fibrous bundle sheath. Generally, different nitrogen sources resulted in a remarkable increase in measurements of all shared tissues in leaf lamina. It is also realized; that no remarkable change was found in the number of spongy parenchyma rows in all investigated treatments. The intercellular space seemed to be wider in case of zero, bio and organic plant compost treatments. It could be stated that the enlargement occurred in the thickness of leaf lamina in all nitrogen treated plants were due neither to the increase in cell size nor to the increase in the number of spongy parenchyma rows. The thickness of leaf main vascular bundle of the organic cattle manure and non organic nitrogen treatments exhibited notable enhancement as compared with the control or both bio and organic plant compost treatments. The enlargements in vascular bundle dimensions of both organic cattle manure and non organic treatments were accompanied by unvarying increments in both average diameter of metaxylem vessels and average thickness of phloem tissue. The average increments percentages in metaxylem vessel diameter of organic cattle manure and non organic treatments were 19.0 and $25.5 \%$ as compared with zero nitrogen treatment. While bio nitrogen and organic plant compost showed comparable same metaxylem vessel diameter 35.05 and $35.2 \mu$. Similar trend of effects was realized in phloem thickness. Since phloem thicknesses were not greatly differed between zero $(63.5 \mu)$, bio $(66.4 \mu)$ and organic plant compost $(69.1 \mu)$ treatments, phloem thickness showed outstanding enlargements with both organic cattle manure and non organic nitrogen treatments.

The present findings support the fact that nitrogen has positive effects on the rate of leaf elongation (Ryle, 1964; Radin, 1983; Volenec and Nelson, 1983 and Gastal and Nelson, 1994) and to a greater extent on leaf internal structure (Mohamed, 1996 and Sakr, 2001).

\section{REFERENCES}

Anonymous (2007). Eurostat newsrelease 80/2007-12 June 2007. www.ec.europa.eu /eurostat.

Anonymous (2009). Strategy of Sustainable Agricultural development. (2030). Agriculture Research Development Center (ARDC). Jan. 2009, 122 pp. (In. Arabic).

Attallah S.A.A.and EL-karamity A.E.(1997). Response of wheat to mineral and biofertilization in the valley and reclaimed lands. J. Agric. Sci., 22(2):319-328.

Azam F., Malik K.A. and Sajjad M.I. (1985). Transformation in soil and availability to plants of $15 \mathrm{~N}$ applied as inorganic fertilizer and legume residues. Plant and Soil 86,3.C. F. Egypt J. Soil Sci., 38 (1-4): 35-54.

Brown M.E. (1976). Role of Azotobacter paspali in association with Paspalum natatum. Journal Applied Bacteria, 40: 341-348.

Döbereiner J. (1977). Present and future opportunities to improve the nitrogen nutrition of crops through biological fixation.in:Biological nitrogen fixation in farming system of the Tropics.Ayanab,M.\&P.J.Dart,eds.Chicester. U.K. C.F. Egypt J. Microbiol., 20: 199-206.

Dommelen A.V., Keijers J., Vanderleyden and Zamaroczy M.De.(1998). (Methyl) ammonium transport in the nitrogen-fixing bacterium Azospirillum brasilense. J. Bacteriol., 10: 2652-2659.

El-Sharaway M.A.O., Aziz M.A. and Ali L.K.M. (2003). Effect of the application of plant residues composts on some soil properties and yield of wheat and corn plant. J. Soil Sci., 43(3): 421-434.

Fayez M., Emam N.F. and Makboul H.E. ( 1985). The possible use of nitrogen fixing Azopirillum as biofertillizer for wheat plants. Egypt J. Microbiol., 20: 199-206.

Forrest C. and Young P.Y. (2006). The effects of organic and inorganic nitrogen fertilizer on the morphology and anatomy of Cannabis sativa (Fédrina) industrial fibre hemp grown in Northern British. J. of Industrial Hemp.,11(2): 3 - 24 .

Gastal F. and Nelson C.J. (1994). Nitrogen use within the growing leaf blade of tall fescue. Plant Physiology, 105: 191-197. 
Hani A., Beauchamp C.J., Goussard N. Chabot R. and Lalande R. (1988). Potential of Rhizobium and Bradyrhizobium species as plant growth promoting rhizobacteria on non-legumes effect on radishes (Raphanus sativus L.). Plant and Soil, 204: 57-67.

Harper S. H. T. and Lynch J. M. (1979). Effect of Azotobacter chroococcum on barley seed germination and seedling development. J. Gen Microbiol, 112: 45:51.

Huang B., Johnson J.W., Nesmith S. and Bridges D.C. (1994). Growth physiological and anatomical responses of wheat genotypes to water logging and nutrient supply. Journal of Experimental Botany, 45(271): 193-202.

Ibrahim S.A., El-leboudi A.E. and Abdel-mez M.R. (1988). A trial for getting benefit from organic wastes of food industry: II- Effect on plant growth and nutrients uptake. Egypt J. Soil Sci. 28,311. C.F. Egypt J. Soil Sci., 38(1-4):35-54.

Jenkison D.S., Fox R.H. and Rayner J.H. (1985). Interactions between fertilizer nitrogen and soil nitrogen the so- called (priming) effect. J. Soil Sci., 36: 425-435.

Kitchen J.L., Mcdonald G.K., Shepherd K.W., Lorimer M.F. and Graham D.R. (2003). Comparing wheat grown in South Australian organic and conventional farming system.1-Growth and grain yield. Aust. J. Agric. Res., 54:889-901.

Kuepper G. (2003). Manures for organic crop production.

http:www.attra.mcat.org/attarpub/

Pbf.Fundamentals of bustainable agriculture.Approprite technology transfer for rural areas (ATTRA).U.S.A. C.F. Pak. J. Bot., 40: 2107-2113.

Mason H., Navabi A., Frick B., Odonovan J., Niziol D. and Spaner D. (2007). Does growing Candian Western hard red spring wheat under organic management alter its bread- making quality? Renew Agric. Food syst., 22:157-167.

Metwally Sh.M. and Khamis M.A. (1998). Comparative effect of organic and inorganic nitrogen sources applied to a sandy soil on availability of $\mathrm{N}$ and wheat yield. Egypt $\mathrm{J}$. Soil Sci., 38: 35-54.

Mohamed E. F. G. (1996). Effect of mineral nutrition on tomy, morphology and chemical composition of some crop plants. MSc Thesis, Cairo University, 138 pp.
Mohamed S. A. (2000). Effect of mineral and biofertilization on growth, yield, chemical constituents and anatomical structure of wheat (Triticum aestivum) and broad bean (Vicia faba L.) plants grown under reclaimed soil. Annals of Agric. Sci. Moshtohor, 38(4): 2039-2063.

MSTAT (1986). Computer software designed for statistical analysis. Version O/Em. Copyrighted June 1982-1986. Michigan stale Univ. Revised 7/1/1986 by: Dept of crop and Soil Sci., Michigan State Univ.

Murphy K.M., Campbell K.G.,Lyon S.R. and Jones G.G.(2007). Evidence of varietal adaptation to organic farming systems. Field Crops Res.,102:172-177.

Nassar M. A. and El-Sahhar K.F. (1988). Botanical Preparations and Microscopy (Microtechnique). Academic Bookshop, Dokki, Giza, Egypt, 219 pp.

Padel S. and Lampkin N. H. (1994). Farm-level performance of organic farming systems. An overview" in N.H. Lampkin, S. Padel (Eds), CAB International Wallingford, 210 -219 .

Popkin R. (1995). Good news for waste watches :Recycling, composting show results for the future. Environ Prot. Agency J. , 21: 18890.

Radin J. W. (1983). Control of plant growth by nitrogen: Differences between cereals and broadleaf species. Plant Cell and Environment, 6: 65-68.

Reynders L. and Valassak K. (1982). Use of Azospirillum brasilense as biofertilizer in intensive wheat cropping. Plant and Soil, 66(2): 217-223.

Ryle G.J.A. (1964). A comparison of leaf and tiller growth in seven perennial grasses as inuenced by nitrogen and temperature. J. of the British Grassland Society, 19: 281-290.

Sabry S.R.S, Saleh S.A. and Ragab A.A. (2000). Response of wheat Triticum aestivum L. to dual inoculation with Azorhizobium caulinodans and VA mycorrhizae under different nitrogen fertilizer levels. Zagazig J. Agric. Res., 27(1): 145-158.

Sakr W.R.A. (2001). Effect of some organic and inorganic fertilizers on Mentha piperita. MSc. Thesis, Cairo University, $155 \mathrm{pp}$.

Sarwat G., Hussain N., Schmeisky H., Suhammad S., Ibrahim M. and Ahmed S. (2008). Efficency of various organic residues for enhancing rice-wheat production under 
normal soil conditions. Pak. J. Bot., 40: 2107-2113.

Smith S.J. and Harpley A.N.(1990). Soil nitrogen mineralization in the presence of surface and incorporated crop resides. Agron. J., 8: 112.

Swarup A. and Yaduvanshi N.P.S. (2000). Effect of intergrated nutrient management on soil properities and yield of rice in alkali soils. Journal of the Indian Science, 48: 279-282.

Volenec J. J. and Nelson C.J. (1983). Response of tall fescue leaf meristems to $\mathrm{N}$ fertilization and harvest frequency. Crop Sci., 23: 720724.

Zahir Z.A., Afzal, A., Ajmal M.,Naveed M.,Asghar H.N. and Arshad M.(2007). Nitrogen enrichment of compost organic wastes for improving growth, yield and nitrogen uptake of wheat.J. Soil and Environ, 26(1):15-21.

Zia M. S., Baig M.B. and Tahir M. B. (1998). Soil environmental issues and their impact on agricultural productivity of high potential areas of Pakistan. Sci. Vision, 4(3): 56-61.

\title{
تأثير المصادر المختلفة للنيتروجين على بعض الصفات النباتية للقمح \\ على محمود صبور- الهام فوزى جمعة ـ شيماء عبد السلام شعبان
}

قسم النبات الزراعى- كلية الزر اعة - جامعة القاهرة

\begin{abstract}
ملخص
اجري هذا البحث فى موسمين متتالين 2006 و 2007 لدر اسة تاثير التسميد بمصادر مختلفة للنيتروجين : السمادالحيوى

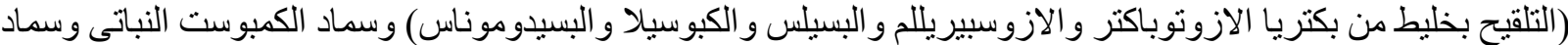

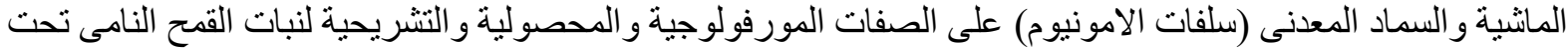

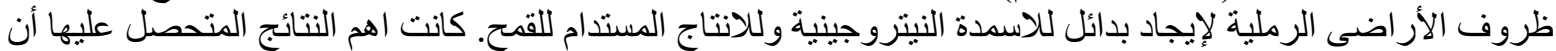

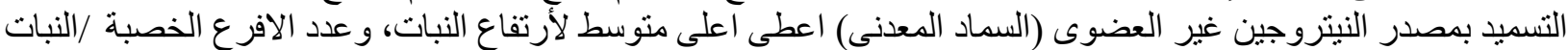

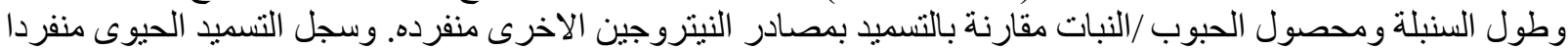

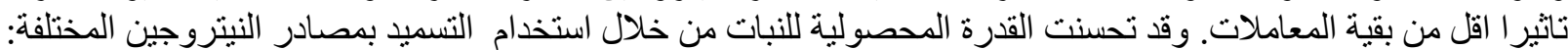

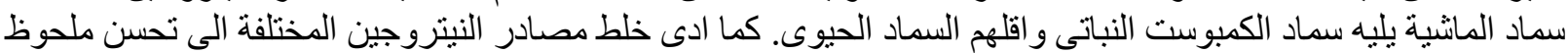

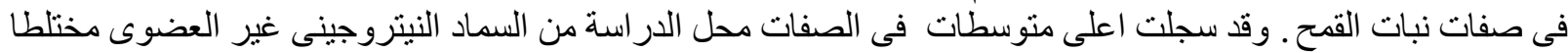

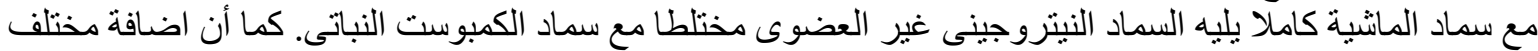

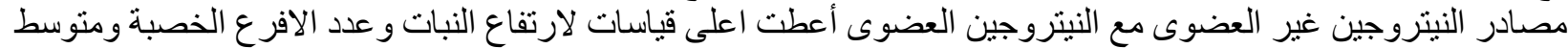

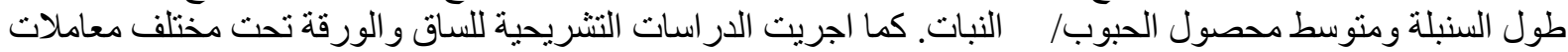

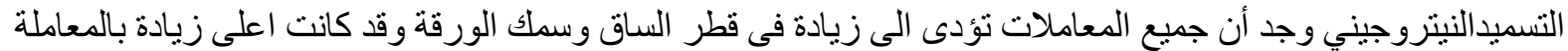

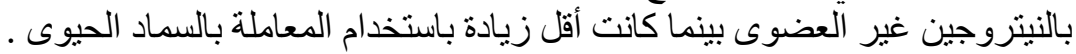

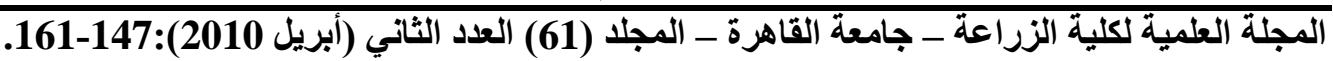

